VOLUME 3 NOMOR 2 JUNI 2020

PERAN STAIN SORONG TERHADAP PENGEMBANGAN KETERAMPILAN BAHASA INGGRIS DI PAPUA BARAT

Bunyamin

STRATEGI PONDOK PESANTREN DALAM MENGHADAPI TANTANGAN GLOBALISASI (STUDI KASUS DI PONDOK PESANTREN API ASRI TEGALREJO MAGELANG)

Ayu Suci Rianingsih, Hairiyah

REKOGNISI KEBIJAKAN PEMERINTAH TERHADAP PESANTREN SEBAGAI LEMBAGA PENDIDIKAN DI INDONESIA

Muh. Mustakim

KONSEP KEPEMIMPINAN DALAM PERSPEKTIF TEOLOGI SYIAH

Kamaluddin Nurdin Marjuni

ISLAMISASI ILMU DALAM KONTEKS PENDIDIKAN ISLAM KONTEMPORER DI INDONESIA

Laelatul Badriah dan Ahmad Syamsul Arifin

ISLAMISASI PENGETAHUAN (TELAAH ATAS PEMIKIRAN SYED NAQUIB AL ATTAS DAN ISMAIL RAJI AL-FARUQI)

Ambar Hermawan 


\title{
PERAN STAIN SORONG TERHADAP PENGEMBANGAN KETERAMPILAN BAHASA INGGRIS DI PAPUA BARAT
}

\section{Bunyamin}

\author{
Jurusan Tarbiyah, STAIN Sorong
}

bunyaminali@yahoo.com

\begin{abstract}
Abstrct
A College has an important role in developing human resources. It has to arrange a good curriculum to answer the need of human in this live. A good curriculum will create a good learning and teaching. The skills are needed by students to face competitions in looking for jobs. English is one of skills which students need in the competition. State Islamic College of Sorong as one of Islamic College in West Papua gives a positive response to answer the students need in a local and global competition. It has three units in building English skills in West Papua. The first is Language Unit. It has done TOEFL Training and Test for students and society. This program develop three skills in English; Listening, Structure, and Reading. The second is Tarbiyah Faculty. It has conducted English Camp for Senior High School Students and University Students. This program improve students' speaking skill. And the third is Bidik Misi. It has done a weekly meeting program. This program helps students to be more active in discussing a topic in English.
\end{abstract}

Keywords: College Role, Development, English Skills. 


\section{PENDAHULUAN}

\section{Bunyamin}

Perguruan Tinggi saat ini sedang mengalami perubahan yang sangat cepat, perubahan dapat dilihat melalui perkembangan masyarakat berbasis ilmu pengetahuan dan teknologi. Masyarakat membutuhkan ilmu pengetahuan dan teknologi untuk menunjang kompetensi mereka baik di tengah-tengah masyarakat maupun dalam persaingan dunia kerja yang semakin kompetitif. Masyarakat yang kurang memiliki ilmu pengetahuan dan teknologi yang dibutuhkan saat ini akan kehilangan kesempatan untuk bersaing di lapangan pekerjaan.Terjemahnya:

Masyarakat harus senantiasa memperbaharui pengetahuan dan keterampilan yang mereka miliki agar mereka bisa bersaing dan berkembang. Hal ini disebabkan oleh perubahan kebutuhan di dunia kerja, dimana banyak perusahaan yang memberi syarat keterampilan baik dalam hal teknologi maupun dalam hal keterampilan. Keterampilan adalah kemampuan pekerjaan secara mudah dan cermat. ${ }^{1}$ Pengertian ini biasanya cenderung pada aktifitas Psikomotor. Keterampilan merupakan kemampuan dalam melakukan hal dengan baik. Kinerja keterampilan meliputi pengetahuan mengenai yang harus dilakukan, kapan dilakukan, dan bagaimana melakukannya.

Kondisi yang demikian memerlukan respon proaktif dari seluruh lapisan masyarakat, terlebih-lebih lagi Perguruan Tinggi sebagai pusat pengembangan Sivitas Akademika yang inovatif, responsif, kreatif, terampil, berdaya saing, dan kooperatif melalui pelaksanaan Tridharma.

Perubahan-perubahan cepat yang terjadi di masyarakat perlu disikapi secara tepat dengan melakukan refleksi mendalam tentang apa peran Perguruan Tinggi yang telah dimainkan sekarang ini.

Perguruan Tinggi saat ini harus mampu menjawab kebutuhan masyarakat yang semakin kompleks. Perguruan Tinggi harus mampu menciptakan inovasi yang menjadi trend kehidupan masyarakat saat ini, sehingga apa yang menjadi kebutuhan dunia kerja bisa dimiliki masyarakat yang menempuh pendidikan di perguruan tinggi tanpa harus mencari keterampilan yang dibutuhkan tersebut di luar kampus.

Salah satu keterampilan yang dibutuhkan saat ini adalah keterampilan bahasa Inggris. Peningkatan keterampilan menjadi kunci sukses menghadapi pasar bebas di era Masyarakat ekonomi ASEAN (MEA). Bahasa Inggris menjadi alat komunikasi yang dominan dan kendaraan untuk dapat memenangkan

${ }^{1}$ Gordon. Definisi Keterampilan. 1994, h. 55 
persaingan global. Kebutuhan akan bahasa Inggris semakin meningkat, tidak hanya di perusahaan multinasional namun juga perusahaan lokal.

Kemampuan bahasa Inggris di era MEA sangat penting, karena dalam perkembangan ekonomi ASEAN, Indonesia akan bekerja sama atau bahkan bersaing dengan negara lain untuk perkembangan ekonomi internasional, dalam hal ini tentunya sangat penting adanya komunikasi yang baik, dan bahasa dalam komunikasi tersebut adalah bahasa Inggris. Dalam MEA, kita dihadapkan dengan persaingan ekonomi internasional dengan negara negara lain yang berarti kita juga harus mengerti bahasa mereka, tetapi tidak mungkin kita harus bisa mengerti banyak bahasa, hanya orang yang memiliki IQ tinggi yang dapat mengerti banyak bahasa. Maka dari itu digunakannya satu bahasa yang dapat dimengerti untuk semua negara yaitu bahasa Inggris yang menjadi bahasa internasional.

Sekolah Tinggi Agama Islam Negeri (STAIN) Sorong merupakan satusatunya Perguruan Tinggi Agama Islam Negeri yang ada di Papua Barat. STAIN Sorong dipandang perlu untuk memiliki peran yang signifikan dalam peningkatan keterampilan mahasiswa, khususnya keterampilan yang dibutuhkan di dunia kerja. STAIN Sorong diharapkan mampu memberi kontribusi yang positif terhadap perkembangan zaman yang kini sudah memasuki zaman MEA.

Keterampilan berbahasa Inggris seperti yang diuraikan di atas sangat dibutuhkan oleh mahasiswa STAIN Sorong. Apabila hal tersebut dimiliki, maka mahasiswa akan menjadi pribadi yang kompeten dan mampu bersaing baik di tingkat lokal maupun global. Namun untuk memiliki kemampuan berbahasa Inggris, diperlukan suatu usaha, tidak dapat terjadi dengan sendirinya. Jadi, diperlukan suatu proses dan hal ini dapat terjadi di STAIN Sorong. Di STAIN Sorong, mahasiswa bisa mendapat penggemblengan, baik dari segi kecerdasan, ketrampilan maupun mental.

\section{PEMBAHASAN}

\section{A. Sejarah STAIN Sorong}

STAIN Sorong yang terletak di Papua Barat sebelumnya bernama Sekolah Tinggi Ilmu Dakwah Al-Hikmah Sorong atau Sekolah Tinggi Agama Islam Swasta (STAIS) Al-Hikmah, STAIN Sorong merupakan perubahan status dari Perguruan Tinggi Agama Islam (PTAI) Swasta menjadi Perguruan Tinggi Agama Islam Negeri (PTAIN). 
TRANSFORMASI: Jurnal Kepemimpinan Dan Pendidikan Islam

Volume: 3 Nomor 2 Juni 2020

Pendidikan Islam Dalam Perspektif Hadis...., H. 1-9

Bunyamin

Sekolah Tinggi Agama Islam Al-Hikmah merupakan lembaga perguruan tinggi Islam yang kedua di Provinsi Papua, setelah perguruan tinggi sebelumnya telah ada di ibu kota Papua (Jayapura). Namun, setelah dilakukan pemekaran wilayah Provinsi Papua menjadi dua bagian, maka wilayah geografi Sorong masuk dalam wilayah Papua Barat. Karenanya, di Provinsi Papua Barat, STAI Al-Hikmah Sorong menjadi perguruan tinggi Islam pertama yang eksis di wilayah tersebut.

Kini, ketika peralihan status menjadi Sekolah Tinggi Agama Islam Negeri (STAIN) Sorong, tidak berarti persoalan yang akan dihadapi tidak ada. Justru, tantangan ke depannya semakin berat, sebab persoalannya semakin kompleks. Kondisi sosial yang majemuk dan meningkatnya populasi masyarakat terhadap tuntutan pekerjaan merupakan aspek penting untuk diperhatikan dalam konteks Kota Sorong dan secara umum Provinsi Papua Barat. Saat ini, STAIN Sorong sudah memiliki 3 Jurusan yaitu Jurusan Dakwah, Tarbiyah dan Syariah.

\section{B. Visi, Misi dan Tujuan}

Visi STAIN Sorong adalah menjadi lembaga pendidikan tinggi yang berakhlak Islami, Populis, dan berdaya saing tinggi. Sedangkan Misinya adalah meningkatkan daya saing melalui pengembangan SIKAP ilmiah, aplikasi nilainilai moral/akhlak, dan pendalaman RASA, persatuan dan kebersamaan (tri strategi pengembangan). Dan Meningkatkan kualitas pelayanan dengan cepat, tepat dan suasana senang (tri marga : CTS).

Adapun tujuan STAIN Sorong adalah menyiapkan peserta didik agar menjadi anggota masyarakat yang memiliki kemampuan akademik dan/atau profesional yang dapat menerapkan, mengembangkan dan/ atau menciptakan ilmu pengetahuan agama Islam, ilmu pengetahuan dan teknologi, serta seni yang dijiwai oleh nilai-nilai keislaman. Mengembangkan dan menyebarluaskan ilmu agama Islam, ilmu pengetahuan dan teknologi, serta seni yang dijiwai oleh nilainilai keislaman, dan mengupayakan penggunaannya untuk meningkatkan taraf kehidupan masyarakat dan memperkaya kebudayaan nasional.

\section{Pentingnya Bahasa Inggris}

Dengan semakin pesatnya perkembangan zaman dan semakin banyaknya perusahaan asing yang dibuka di Indonesia, banyak calon karyawan yang berusaha untuk memiliki kemampuan dalam bahasa Inggris dengan fasih. Kebanyakan perusahaan mencari karyawan yang mampu mengikuti ritme dan komunikasi dengan klien yang berkebangsaan asing. Oleh karena itu, seleksi yang ketat saat interview diterapkan oleh beberapa perusahaan ternama. Mereka 
TRANSFORMASI: Jurnal Kepemimpinan Dan Pendidikan Islam

Volume: 3 Nomor 2 Juni 2020

Pendidikan Islam Dalam Perspektif Hadis...., H. 1-9

Bunyamin

pastinya tidak ingin menerima calon karyawan yang tidak berkompeten dan fasih dalam penguasaan bahasa asing.

Berbicara bahasa Inggris yang fasih bisa menjadi nilai tambah tersendiri bagi orang yang ingin melamar pekerjaan. Banyak perusahaan yang menekankan bahasa Inggris pada sesi wawancara ketika ada perekrutan karyawan baru. Banyak perusahaan di Indonesia yang menuntut para karyawannya menggunakan bahasa Inggris baik secara aktif maupun pasif. Hal ini juga di maksudkan untuk menaikkan citra perusahaan di mata masyarakat dan investor maupun klien mereka.

Perkembangan Ilmu pengetauan dan teknologi yang tidak bisa dibendung lagi dan terus berkembang pesat. Berada pada era globalisasai dan informasi ini, bangsa Indonesia dituntut mampu bersaing dengan bangsa-bangsa lain dalam berbagai bidang. Untuk dapat beradaptasi dengan tatanan kehidupan yang semakin maju, peningkatan sumber daya manusia harus diutamakan.

Pentingnya penguasaan bahasa Inggris telah lama disadari oleh pemerintah Indonesia terbukti dengan menjadikan bahasa asing tersebut sebagai salah satu mata pelajaran yang diajarkan di sekolah-sekolah, baik di sekolah swasta maupun negeri. Bahkan bahasa Inggris telah diajarkan di sekolah-sekolah di Indonesia sejak awal kemerdekaan republik ini. ${ }^{2}$

\section{Keterampilan Bahasa Inggris}

Mahasiswa yang mau memiliki kemampuan bahasa Inggris harus menguasai 4 (empat) keterampilan dalam bahasa Inggris, yaitu Speaking (berbicara), Listening (mendengar), Reading (membaca) dan Writing (menulis). Selain itu, penunjang dari keempat keterampilan itu adalah Grammar, Vocabulary dan Pronunciation.

\section{Speaking (Berbicara)}

Speaking merupakan keterampilan yang banyak diminati oleh mahasiswa yang mau mahir dalam bahasa Inggris. Berbicara menggunakan bahasa Inggris merupakan sarana untuk berkomunikasi dengan banyak orang dari berbagai negara, karena bahasa Inggris menjadi bahasa pengantar di berbagai Universitas baik di dalam Negeri maupun di luar Negeri.

2 Rachmajanti, S. 2004. The Impacts of the Teaching English at the Elementary Schools of the Students' Achievement of the English at the First Year of Lower Secondary Schools. Disertasi tidak diterbitkan. Malang: Program Pascasarjana, Universitas Negeri Malang 
TRANSFORMASI: Jurnal Kepemimpinan Dan Pendidikan Islam

Volume: 3 Nomor 2 Juni 2020

Pendidikan Islam Dalam Perspektif Hadis...., H. 1-9

Bunyamin

Speaking adalah proses interaktif dari membangun makna yang terdiri dari memproduksi, menerima dan mengolah informasi ${ }^{3}$ (Brown, 2001: 267). Bentuk dan makna dari berbicara itu tergantung pada konteks di mana pembicaraan itu terjadi. Pada umumnya, berbicara menggunakan bahasa Inggris dipakai sebagai alat komunikasi oleh mahasiswa di dalam kampus dan karyawan yang bekerja di perusahaan asing. Jadi kehadiran pembicara dan pendengar adalah mutlak untuk terjalinnya komunikasi tersebut.

\section{Listening (Mendengar)}

Listening adalah istilah luas yang digunakan terhadap proses cognitive, affective, dan behaviour yang kompleks. ${ }^{4}$ Proses affective adalah motivasi untuk menghadirkan orang lain; proses cognitive adalah kemampuan memahami, menerima dan menafsirkan isi dari pesan yang kita dengar; dan proses behavior adalah adanya respon umpan balik baik berupa verbal maupun nonverbal.

Listening adalah bagaimana kita memahami apa yang kita dengar dalam bahasa inggris. Baik itu secara langsung maupun tidak langsung melalui media seperti mendengar musik atau menonton film. Listening merupakan keterampilan yang sangat dibutuhkan dalam bahasa Inggris karena kita harus mampu memahami apa yang orang lain ucapkan pada kita. Hal ini sangat ditunjang oleh kemampuan vocabulary kita, semakin banyak vocabulary yang kita kuasai maka akan semakin mudah bagi kita untuk memiliki keterampilan listening.

\section{Reading (Membaca)}

Reading proses memahami makna dari teks. ${ }^{5}$ Reading adalah aktifitas fisik dan mental untuk mengngkapkan makna dari teks yang tertulis. Aktifitas fisik itu melibatkan mata kita untuk membaca huruf, kata dan kalimat dari sebuah bacaan, sedangkan aktifitas mental adalah adanya persepsi dan ingatan yang harus dilibatkan pada saat kita mencoba memahami yang dibaca.

Reading adalah proses cognitive yang kompleks dimana kita harus mengetahui apa yang kita baca dan memahami makna yang terkandung di

${ }^{3}$ Brown, H.D. 2001. Teaching by Principles: An Interactive Approach to Language Pedagogy (2nded.). New York: Addison Wesley Longman, Inc, h. 267.

${ }^{4}$ Halone, Kelby; Cunconan, Terry; Coakley, Carolyn; Wolvin, Andrew (1998). "Toward the establishment of general dimensions underlying the listening process.". International Journal of Listening. 12: 12-28.

5 Cline, F., Johnstone, C., \& King, T. (2006) Focus Group Reaction to Three Definition of Reading (as Originally Developed in Support NARAP Goal 1). Minneapolis, M.N.: National Accessible Reading Assesment Project, h. 2. 
TRANSFORMASI: Jurnal Kepemimpinan Dan Pendidikan Islam

Volume: 3 Nomor 2 Juni 2020

Pendidikan Islam Dalam Perspektif Hadis...., H. 1-9

Bunyamin

dalamnya. Reading adalah alat untuk menguasai bahasa Inggris, dan alat untuk untuk berbagi ilmu dan ide, sehingga dalam proses Reading tersebut terjadi interaksi antara pembaca dan yang dibaca yang terbentuk dari pemahaman dasar dan pengalaman dari pembaca tersebut. Pemahaman harus didasari oleh maksud dan tujuan kita membaca, ketika tujuan kita membaca sangat jelas maka tingkat pemahaman juga akan lebih baik.

\section{Pengembangan Keterampilan Bahasa Inggris di Stain Sorong}

Keberhasilan sebuah perguruan tinggi sangat ditentukan oleh sejauh mana sumber daya manusia yang dihasilkan mampu menguasai ilmu pengetahuan dan teknologi untuk dimanfaatkan di tengah-tengah masyarakat. Salah satu lembaga yang relevan dan bertanggung jawab untuk menghasilkan sumber daya manusia unggul dan berkualitas yang menguasai ilmu pengetahuan dan teknologi adalah Perguruan Tinggi Agama Islam (PTAI). Perguruan Tinggi Agama Islam sebagai pusat pendidikan Islam hendaknya mampu mencetak SDM yang kompeten untuk menghadapi era globalisasi yang penuh dengan tantangan dan persaingan. Tingkat kemajuan bangsa sangat ditentukan oleh kemajuan dan perkembangan perguruan tingginya. Namun kemajuan dan kualitas sebuah perguruan tinggi juga sangat ditentukan oleh lulusan sekolahsekolah menengah atas yang menempuh pendidikan di perguruan tinggi tersebut.

PTAI memiliki tantangan yang tidak sederhana, banyak keterampilan yang harus dikuasai, tetapi tidak sedikit yang belum melakukan hal itu. Tantangan itu adalah pengembangan ilmu pengetahuan dan keterampilan yang dibutuhkan di dunia kerja. Apalagi begitu banyak produk atau ilmu sains dan teknologi yang cukup signifikan yang dikuasai oleh orang-orang dari perguruan tinggi agama Islam. Tantangan yang dihadapi perguruan tinggi berkaitan dengan fungsi dan tugas perguruan tinggi.

Perguruan tinggi adalah sebuah alat kontrol masyarakat dengan tetap terpeliharanya kebebasan akademis terutama dari campur tangan penguasa. Perguruan tinggi juga merupakan agen utama pembaharuan dalam kehidupan bernegara, seperti dalam proses pembentukan pemerintah orde baru tahun 1970- an dimana peran nyata yang telah di mainkan kalangan dosen dengan mahasiswa dengan cara-caranya sendiri telah memberikan sumbangan besar bagi pemerintah orde baru. ${ }^{6}$ Indonesia.

${ }^{6}$ Syarbaini, Syahrial. 2009. Pendidikan Pancasila Di Perguruan Tinggi. Bogor : Ghalia 
Perguruan tinggi merupakan penghasil tenaga kerja yang dibutuhkan dunia kerja. Perguruan tinggi harus mampu menghasilkan mahasiswa yang mempunyai nilai atau harga (value) dalam pasaran kerja, dan keberhasilan itu dapat dilihat melalui penyerapan lulusan dalam masyarakat. Mahasiswa yang mempunyai nilai akan mampu bersaing dalam perebutan lapangan pekerjaan yang semakin kompetitif.

Berdasarkan data kegiatan 2016 di STAIN Sorong, ada 3 unit di STAIN Sorong yang berperan terhadap pengembangan keterampilan bahasa Inggris. Pertama, Pusat Bahasa yang pada tahun 2016 dipimpin oleh Dr. H. Surahman Lc., M.A.; Kedua, Jurusan Tarbiyah yang dipimpin oleh Sukman S, S.Ag., M.Pd.I; dan Ketiga, Pengelola Bidik Misi yang dipimpin oleh Dr. Muhammad Rais Amin, S.Ag., M.Ag.

Pusat Bahasa melaksanakan kegiatan Pelatihan dan Toefl Test yang menghadirkan pemateri dari Makassar. Kegiatan ini sangat dibutuhkan oleh mahasiswa atau masyarakat yang membutuhkan kemampuan dalam mengerjakan Soal-soal Toefl. Soal Toefl ini membutuhkan 3 keterampilan dalam bahasa Inggris, yakni keterampilan listening, reading dan written expression, sehingga kegiatan ini sangat membantu mahasiswa atau masyarakat yang kurang memiliki ketiga keterampilan tersebut.

Jurusan Tarbiyah pada tahun 2016 melaksanakan kegiatan English Camp yang lebih menekankan pada keterampilan Speaking peserta. Kegiatan ini mengajarkan kepada peserta bagaimana berkomunikasi dengan baik menggunakan bahasa Inggris. Peserta dituntun untuk bisa berbicara baik dalam kondisi formal maupun non formal, sehingga keterampilan speaking peserta bisa jauh lebih baik.

Adapun Pengelola Bidik Misi melaksanakan kegiatan weekly meeting setiap hari minggu di kampus STAIN Sorong. Peserta dalam kegiatan ini adalah mahasiswa penerima beasiswa Bidik Misi dari semua jurusan, yang terdiri dari jurusan Tarbiyah, Jurusan Dakwah dan Jurusan Syari'ah. Kegiatan ini lebih difokuskan pada english discussion yang membahas tema-tema yang terbaru, baik yang berkaitan dengan dunia pendidikan maupun yang berkaitan dengan sosial dan budaya.

\section{KESIMPULAN}

Berdasarkan pembahasan tersebut, kita dapat menarik kesimpulan bahwa STAIN Sorong memiliki peran yang sangat besar terhadap pengembangan keterampilan bahasa Inggris di Papua Barat. STAIN Sorong 
TRANSFORMASI: Jurnal Kepemimpinan Dan Pendidikan Islam

Volume: 3 Nomor 2 Juni 2020

Pendidikan Islam Dalam Perspektif Hadis...., H. 1-9

Bunyamin

memahami kebutuhan mahasiswa dan masyarakat saat ini yang membutuhkan ilmu pengetahun, teknologi dan keterampilan yang akan digunakan di dunia kerja dan di tengah-tengah masyarakat.

STAIN Sorong memiliki 3 unit yang membantu terlaksananya peran STAIN Sorong terhadap pengembangan keterampilan bahasa Inggris di Papua Barat. Hal ini tentu sangat baik bagi peningkatan SDM khususnya dalam bidang bahasa Inggris, sehingga mahasiswa yang menyele saikan studinya di STAIN Sorong bisa bersaing dengan mahasiswa dari Universitas atau sekolah tinggi lain dalam dunia kerja.

\section{DAFTAR PUSTAKA}

Brown, H.D. 2001. Teaching by Principles: An Interactive Approach to Language Pedagogy (2nded.). New York: Addison Wesley Longman, Inc.

Cline, F., Johnstone, C., \& King, T. (2006) Focus Group Reaction to Three Definition of Reading (as Originally Developed in Support NARAP Goal 1). Minneapolis, M.N.: National Accessible Reading Assesment Project.

Gordon. Definisi Keterampilan. 1994

Halone, Kelby; Cunconan, Terry; Coakley, Carolyn; Wolvin, Andrew (1998). "Toward the establishment of general dimensions underlying the listening process.”. International Journal of Listening. 12: 12-28.

Rachmajanti, S. 2004. The Impacts of the Teaching English at the Elementary Schools of the Students' Achievement of the English at the First Year of Lower Secondary Schools. Disertasi tidak diterbitkan. Malang: Program Passcasarjana, Universitas Negeri Malang

Syarbaini, Syahrial. 2009. Pendidikan Pancasila Di Perguruan Tinggi. Bogor : Ghalia Indonesia. 